\title{
Level of emotional intelligence and its association with person- related characteristics among grade 8 students in a suburban setting
}

\author{
M.S. Lankashini ${ }^{1}$, V.G.D. Lakmali ${ }^{1}$, S.A.K. Lenagala ${ }^{1}$ A.L.R.P. Liyanage $^{1}$, C. Arambepola ${ }^{2}$ \\ ${ }^{1}$ Medical student, Faculty of Medicine, University of Colombo \\ ${ }^{2}$ Senior lecturer, Department of Community Medicine, Faculty of Medicine, Colombo
}

\begin{tabular}{l} 
A R T I C L E I N F O \\
\hline Article history: \\
Submission 11.02.17 \\
Acceptance 20.05.2017 \\
Available online
\end{tabular}

DOI:

http://10.4038/cjms.v54i1.4805

Keywords:

Emotional intelligence

Adolescents

Person-related characteristics

\begin{abstract}
Background: The concept of Emotional Intelligence (EI) has become an emerging topic in the field of clinical psychology in recent years, especially in relation to adolescents. Although many studies have been conducted globally, limited evidence is available in Sri Lanka on its magnitude and person-related factors affecting it in school population.

Objectives: To describe the level of EI and to determine its relationship with demographic and socio-economic characteristics among Grade eight students in a suburban setting

Methods: A school-based cross-sectional study was conducted in 2015 among male and female Grade eight students in Embilipitiya educational zone. Eight classes were randomly selected as 'clusters' from two purposively selected mix schools. A self-administered questionnaire assessed the level of EI (based on scores obtained for 15 constructs using the validated TEIQue-ASF questionnaire) and demographic and socio-economic characteristics (gender; parental education, occupation and monthly income; birth order and number of siblings). Based on the mean score, participants were categorized as having 'good' or 'poor' level of EI. The associations of EI with socio-economic characteristics were assessed for significance using $t$ and Chi-square tests.

Results: Response rate was 87\%. Mean score obtained for EI was 144 ( $\mathrm{SD}=17.3$ ) with students scoring low in impulsiveness (mean=6.69, $\mathrm{SD}=2.91$ ), emotion perception (mean=7.71, $\mathrm{SD}=2.52$ ) and adaptability (mean=7.99, $\mathrm{SD}=2.87$ ). 'Good' level of EI was noted in $49.4 \%$ of all students. A significantly higher proportion of female students showed a 'good' level of EI (54.5\%) compared to $43.1 \%$ among the males $(\mathrm{p}=0.04)$.

Conclusion: Nearly $50 \%$ of students demonstrated a 'good' level of EI. Female students were emotionally more intelligent than their male counterparts. No other socio-economic characteristic was associated with 'good' EI.
\end{abstract}

\section{Background}

Emotional Intelligence (EI) refers to the ability of humans to recognize, regulate and handle emotions [1]. It encompasses a wide variety of abilities such as being able to motivate one and

\section{Corresponding Author:}

M. S. Lankashini

Faculty of Medicine, Colombo 08 , Sri Lanka mslankashini@yahoo.com

http://orcid.org/0000-0001-8334-4658 abilities such as being able to motivate one and persist in the face of frustration, to control impulses and delay gratification, to regulate one's mood and keep distress from diminishing the ability to think, and to empathize and hope. Earliest evidence on the importance of such human ability is traced back to Charles Darwin's work on emotional expression for survival and its second adaptation [2]. The term 'emotional intelligence' was coined in 1990 by Peter Salevoy \& John Mayer as 'the ability to perceive accurately, appraise and express emotion; the ability 
to access and/or generate feelings when they facilitate thought; the ability to understand emotion and emotional knowledge; and the ability to regulate emotions to promote emotional and intellectual growth' [3].

In the past decade, EI has generated an enormous amount of interest both within and outside the field of psychology in relation to working environment, leadership and relationship among individuals [4]. It is identified as a vital indicator of overall success in life and an essential component for manifesting human potentials [1]. The ability to balance the body and mind, which has an impact on the overall wellbeing, is heavily tied with emotional intelligence [4]. It is also shown to directly correlate with positive attitudes and a happier outlook of life [1], all of which help to alleviate anxiety and prevent depression and mood swings in a person. Understanding the needs, feelings and responses of others leads to stronger and fulfilling relationships with each other, and thereby paving way to become stronger internal motivators who can generate selfconfidence and improve the ability to focus on life goals [2].

Intelligent Quotient (IQ), the main factor contributing to the popularity of EI is that it can be learnt, practised and improved [1]. As such, if instilled at an early age, EI can positively affect the transformation of children into better adults. While home is often regarded as the place where the learning of emotional skills begins, school is the prime location for promotion and further teaching of EI. While emotional coaching by parents helps a child in his development, EI is equally important in social adjustments among adolescents. Representing a crucial age for greater change in behaviour, youth is a period of physical and psychological maturity, when an individual is expected to establish his own identity and to develop necessary skills for socially responsible behaviour. Moreover, living in a fast paced technological world, children spend more time on virtual social networks, creating a greater need than ever to develop EI from an early age.

EI among school children is a dynamic construct influenced by several external factors. Many studies have shown a relationship of EI with sociodemographic characteristics such as age, sex, locality and socioeconomic status [7,9,10, and 12]. However, there is still no consensus on the influence of these variables on EI.
Sri Lanka is driven by a traditional education system that mainly focuses on the academic performance that assesses predominantly the IQ, leading to elitism and expecting them to be among the best which is synonymous with success, power and money [5]. In this backdrop, assessing the level of their EI will shed light on their emotional preparedness for becoming future socially responsible adults. Also, identifying the factors associated with such EI will enable the policy makers and educationists to revisit the school curricula to suit children of modern world. Although studies have been done on this topic in various countries $[9,10,12]$, only one research has been carried out in Sri Lanka [7] on the magnitude and associated factors of EI among Advanced Level students. This study aimed to describe the level of EI among Grade 8 students in a suburban setting in Sri Lanka and to identify its relationship with their socioeconomic characteristics.

\section{Methods}

A school-based cross-sectional study was conducted among Grade 8 students in Embilipitiya educational zone. The setting represented secondary schools of Sinhala medium with male and female students of varying social backgrounds in a suburban setting. Students with special needs were excluded. Using cluster sampling method, a total of 322 students was recruited from eight classes in Grade 8, which were randomly selected as 'clusters' from two purposively selected mix schools. Prior to data collection, informed written consent was obtained from eligible students and their parent/guardian. Administrative clearance was obtained from the principals of each selected school. Ethical clearance was obtained from the Ethics Review Committee of the Faculty of Medicine, University of Colombo.

A self-administered questionnaire was administered to the parents of eligible students to assess demographic and socio-economic characteristics such as age and gender of student, parental education and occupation, monthly family income, number of children in the family and birth order of student in the family.

Emotional intelligence was assessed by students themselves using TEIQue-Adolescent Short Form questionnaire. This tool had been previously validated for its criterion and incremental validity in the United Kingdom, New Zealand, Spain and Asian countries [6]. The questionnaire was translated into Sinhala language using backward-forward translation method, in which one person fluent in both languages translated the questionnaire from 
English to Sinhala and then another similar but an independent person translated it back to English language. At the end, it was compared with the original questionnaire for any discrepancies, with due consideration given to cultural appropriateness and local favourable language. Each item was assessed for its appropriateness and acceptability in the local context by a public health specialist. Finally, it was pre-tested in a group of students from a different school from the same area to ensure face and content validity of the tool.

TEIQue questionnaire comprises of 30 short statements, two for each of the 15 trait emotional intelligence facets (adaptability, assertiveness, emotion perception, emotion expression, emotion regulation, emotion management, self-esteem, selfmotivation, social awareness, stress management, trait empathy, trait happiness, trait optimism, low impulsiveness, and relationships) [6]. Responses were scored using a pre-determined scoring system (including reverse scoring) on a seven-point scale, ranging from 1 (strongly disagree) to 7 (strongly agree). The score ranged from 30 to 210 , with higher scores indicating higher levels of the trait emotional intelligence. Classification of the students into 'Good' ( $\geq 144$ marks obtained) and 'Poor' ( $<144$ marks obtained) levels of EI was based on the mean score of 144 obtained for overall EI which was thus considered as the cut-off.

\section{Results}

A total of 322 students participated, giving a response rate of $87 \%$. Of them, $44.7 \%$ were males. Descriptive characteristics of the students are shown in Table 1. Most of the students were the first-born child in their families $(52.5 \%)$ with a monthly family income of Rs.20,001-40,000 (38.5\%). Nearly $70 \%$ of mothers were housewives and $55.6 \%$ fathers were employed as semi-skilled labourers. Most of the parents have had an education to level between Grades 6-11.

Emotional intelligence scores ranged between 89 and 194 (Figure 1). Median score was 143 and the mean score was $144(\mathrm{SD}=17.3)$. The mean score of female students was $145.7(\mathrm{SD}=17.3)$ compared to $141.7(\mathrm{SD}=16.6)$ of male students.

A summary of the mean scores obtained by students for each sub-component of EI is given in Table 2. Students scored least in the sub-components of low impulsiveness, emotion perception and adaptability. Happiness, self-esteem and social awareness and stress management were the sub-components which received the highest scores. Of these, both male and female students scored less than seven for lowimpulsiveness and emotion perception, and scored above 10 for happiness, social awareness and selfesteem. When each sub-component was considered, female students received higher scores over their male counterparts in all sub-components of EI except assertiveness.

The total number of students having a 'good' level of EI was $163(50.6 \%)$ compared to 159 students who had a 'poor' level. When comparing the two groups, the mean scores obtained for each subcomponent of EI were all significantly greater in the group having a 'good' level $(\mathrm{p}<0.01)$.

Demographic and socio-economic factors associated with the level of EI are shown in Table 3. The proportion of female students having 'good' EI $(54.5 \%)$ was significantly higher than the proportion of male students $(43.1 \%)\left(\chi^{2}=4.167, \mathrm{p}=0.04\right)$. There was no other association between level of EI and student characteristics.

\section{Discussion}

Our study describes the level of EI among selected group of students from Grade 8 and its association with gender. Among the 322 students who participated in this study, nearly half of the students $(159,49.4 \%)$ showed a 'good' level of EI. This proportion is difficult to compare with previous studies due to differences in tools administered for assessing EI.

Trait emotional intelligence consists of 15 subcomponents. In this study, we have shown that both male and female students were poor in lowimpulsiveness, emotion perception and adaptability, all of which reflect their difficulty in managing emotions [7]. Low impulsivity involves thinking before acting and reflecting carefully before making decisions. Low scorers tend to be impetuous and give into their urges. They often speak without thinking through, and change their mind frequently [6]. Emotion perception measures the perception in one's own self as well as in others. Low scorers tend to confuse about how they feel and do not pay much attention to the others emotional signals [6]. Persons having high adaptability skills are flexible in their approach to work and life whereas low scorers are change-resistant and find it difficult to modify their work and lifestyle. They are generally inflexible and have fixed ideas and views. Findings in our study demonstrate poor abilities in these three aspects among suburban adolescents and emphasizes the difficulties they encounter in managing their own emotional situations. In Sri Lanka, school 
adolescents face a lot emotional challenge in an overly competitive academic environment. While emotional coaching by parents being helpful in early years of life, similar coaching by teachers at schools is equally important during adolescence in the later stages of development [8].

Female students being emotionally more intelligent than their male counterparts in our study is consistent with findings by Joshi \& Dutta among school children aged 14-16 years [9] and study done by Archana Nara [10]. However, our findings contrast a study done in Sri Lanka by Jayawardane \& Jayawardane in 2009 among Advanced Level students, in which boys showed a slightly higher level of EI over girls [7], with higher scores reported for emotion expression, self-awareness, emotional awareness of others and emotional reasoning among males. In contrast, females in our study showed higher scores for all sub-components except assertiveness.

Emotional intelligence researches in adults frequently conclude that women score higher than men. Daniel Goleman in his article "Are women more emotionally intelligent than men?" describes that "women tend to have an edge over men when it comes to basic skills for a happy and successful life. Some measures suggest that women are on average better than men at some forms of empathy and men do better than women when it comes to managing distressing emotions" [11]. This argument is supported by conventional theories showing that women have a greater understanding and are more sensitive to emotions of the others. Both men and women have EI, but each gender has a significantly different EI profile. Women have much stronger interpersonal skills than their male counterparts, whereas men have significantly higher sense of self and independence [2].

Boys in particular often struggle with EI due to cultural norms that suggest it is 'less manly' to acknowledge or admit emotions. A study from the School of Psychology in University of Surrey describes how gender related differences in EI propagate across generations. Mothers talk more about emotions than fathers, and parents discuss emotional situations more with girls than boys, so that girls may learn more about emotions than boys. Moreover, children may perceive that it is more appropriate for girls to discuss emotions. This inevitably leads to girls growing up more equipped to cope up with emotions. Therefore, it is of utmost importance that boys as well as parents are made aware of the importance of EI [12].
In our study, compared to males, female students received higher scores for all except assertiveness. It is shown that persons with assertiveness are forthright and frank [6]. They know how to ask for things, give and receive compliments, and confront others when necessary. Low scorers tend to backdown even if they know they are correct, and have difficulty in saying 'no,' even when they know they must. As a result, they often end up doing things they do not want to do.

In this study, no person-related characteristic other than gender seemed to associate with EI. In concurrence, a study done in India by Rama Devi \& Narayanamma showed that emotional intelligence is independent of father's education and occupation, mother's education and family income, but not of mother's occupation [13]. In contrast to this, a study conducted by Harrod \& Scheer indicated that EI level is positively related to parent's education and household income [14]. This contradictory finding may be due to considerable socio-cultural differences existing between the two study settings. Thus, further research on varying socio-cultural contents focusing on socio-economic characteristics will add vitality to the existing knowledge on factors affecting EI.

\section{Limitations}

Since this analysis relied on self-reported information, participants might either over-report or under-report their responses to disguise their true feelings and to create the image that they are intelligent. Further, since the sample was restricted to a single educational zone, the findings may not be applicable to the entire suburban school population of Sri Lanka. Though face and content validity was established prior to use, TEIQue has not been validated for Sri Lanka in a comprehensive validation study, thus findings based on it should be cautiously interpreted.

\section{Conclusions}

Nearly $50 \%$ of the students had a 'good' level of EI, with scores significantly higher in all 15 subcomponents of EI compared to those with 'poor' level. However, students scored relatively poor in low impulsiveness, emotion perception and adaptability aspects of EI. Of the person-related characteristics, 'being a female' was the only factor associated with 'good' level of EI. Female students scored higher in all aspects of EI other than being assertive. 


\section{Acknowledgement}

This research was carried out as a requirement of the Community Stream undergraduate academic programme of the Faculty of Medicine, University of Colombo, Sri Lanka.

Table 1: Distribution of the demographic \& socio-economic characteristics of students

\begin{tabular}{|c|c|c|}
\hline $\begin{array}{l}\text { Demographic \& Socio-economic } \\
\text { characteristics }(\mathrm{N}=322)\end{array}$ & No. & $\%$ \\
\hline \multicolumn{3}{|l|}{ Gender } \\
\hline Male & 144 & 44.7 \\
\hline Female & 178 & 55.3 \\
\hline \multicolumn{3}{|l|}{ Birth order in the family } \\
\hline $1^{\text {st }}$ child & 169 & 52.5 \\
\hline $2^{\text {nd }}$ child & 103 & 32.0 \\
\hline $3^{\text {rd }}$ or $>3^{\text {rd }}$ & 50 & 15.1 \\
\hline \multicolumn{3}{|l|}{ Monthly family income (Rs.) ${ }^{a}$} \\
\hline$\leq 20,000$ & 122 & 37.9 \\
\hline $20,001-40,000$ & 124 & 38.5 \\
\hline$>40,000$ & 71 & 22.0 \\
\hline \multicolumn{3}{|l|}{ Father's employment $^{\mathrm{b}}$} \\
\hline Professional & 79 & 24.5 \\
\hline Self-employed & 52 & 16.1 \\
\hline Semi-skilled labourer & 179 & 55.6 \\
\hline Unemployed & 5 & 1.6 \\
\hline \multicolumn{3}{|l|}{ Mother's employment } \\
\hline Employed & 96 & 29.8 \\
\hline Housewife & 226 & 70.2 \\
\hline \multicolumn{3}{|l|}{ Number of children in the family } \\
\hline One & 30 & 9.3 \\
\hline Two & 148 & 46.0 \\
\hline Three & 95 & 29.5 \\
\hline More than three & 49 & 15.2 \\
\hline \multicolumn{3}{|l|}{ Father's highest educational level ${ }^{\mathrm{c}}$} \\
\hline Not attended school or Grade 1-5 & & 3.7 \\
\hline Grade 6-11 & 12 & \\
\hline Passed O/Level examination & & 38.2 \\
\hline \multirow{5}{*}{ Passed A/Level examination } & 123 & \\
\hline & & 34.5 \\
\hline & 111 & \\
\hline & & 22.1 \\
\hline & 71 & \\
\hline \multicolumn{3}{|l|}{ Mother's highest educational level } \\
\hline Not attended school or Grade 1-5 & 11 & 3.4 \\
\hline Grade 6-11 & 144 & 44.7 \\
\hline Passed O/Level examination & 99 & 30.7 \\
\hline Passed A/Level examination & 68 & 21.1 \\
\hline
\end{tabular}


Table 2: Mean scores of emotional intelligence according to the gender of students

\begin{tabular}{|c|c|c|c|c|c|c|}
\hline \multirow{2}{*}{$\begin{array}{l}\text { Factors of } \\
\text { emotional } \\
\text { intelligence }\end{array}$} & \multicolumn{2}{|l|}{ Female } & \multicolumn{2}{|l|}{ Male } & \multicolumn{2}{|l|}{ Total } \\
\hline & Mean & SD & Mean & SD & Mean & SD \\
\hline $\begin{array}{l}\text { Emotion } \\
\text { expression }\end{array}$ & 9.23 & 2.52 & 8.79 & 2.38 & 9.03 & 2.47 \\
\hline Empathy & 8.66 & 2.62 & 8.89 & 2.67 & 8.76 & 2.67 \\
\hline Self-motivation & 10.85 & 2.52 & 8.89 & 2.74 & 10.68 & 2.59 \\
\hline $\begin{array}{l}\text { Emotion } \\
\text { regulation }\end{array}$ & 9.15 & 2.82 & 8.97 & 3.08 & 9.07 & 2.94 \\
\hline Happiness & 12.25 & 2.39 & 11.81 & 2.43 & 12.06 & 2.42 \\
\hline Social awareness & 11.23 & 2.38 & 10.86 & 2.53 & 11.07 & 2.46 \\
\hline $\begin{array}{l}\text { Low } \\
\text { impulsiveness }\end{array}$ & 6.70 & 2.70 & 6.66 & 3.15 & 6.69 & 2.91 \\
\hline $\begin{array}{l}\text { Emotion } \\
\text { perception }\end{array}$ & 7.73 & 2.55 & 7.68 & 2.48 & 7.71 & 2.52 \\
\hline Self- esteem & 12.02 & 2.04 & 12.00 & 2.07 & 12.02 & 2.06 \\
\hline Assertiveness & 8.35 & 3.02 & 8.51 & 3.06 & 8.43 & 3.04 \\
\hline $\begin{array}{l}\text { Emotion } \\
\text { management }\end{array}$ & 9.35 & 2.66 & 8.85 & 2.42 & 9.13 & 2.57 \\
\hline Optimism & 11.05 & 2.74 & 10.38 & 3.01 & 10.75 & 2.89 \\
\hline Relationships & 9.93 & 2.98 & 9.52 & 3.11 & 9.75 & 3.05 \\
\hline Adaptability & 8.16 & 2.84 & 7.77 & 2.89 & 7.99 & 2.87 \\
\hline $\begin{array}{l}\text { Stress } \\
\text { management }\end{array}$ & 11.0 & 2.39 & 10.56 & 2.75 & 10.81 & 2.57 \\
\hline
\end{tabular}

Table 3: Association of demographic and socio-economic characteristics with the level of emotional intelligence

\begin{tabular}{|c|c|c|c|c|c|c|}
\hline \multirow{3}{*}{$\begin{array}{l}\text { Socio-economic } \\
\text { characteristic }\end{array}$} & \multicolumn{4}{|c|}{$\begin{array}{l}\text { Level of emotional } \\
\text { intelligence }\end{array}$} & \multirow{3}{*}{$\begin{array}{l}\text { Tot } \\
\text { al }\end{array}$} & \multirow{3}{*}{$\begin{array}{l}\text { Level of } \\
\text { signific } \\
\text { ance }\end{array}$} \\
\hline & \multicolumn{2}{|c|}{ Poor } & \multicolumn{2}{|c|}{ Good } & & \\
\hline & $\begin{array}{l}\mathbf{N} \\
\mathbf{0}\end{array}$ & $\%$ & $\begin{array}{l}\mathbf{N} \\
\mathbf{0}\end{array}$ & $\%$ & & \\
\hline Gender & & & & & & \\
\hline Female & 81 & 45.5 & 97 & 54.5 & 178 & $\begin{array}{l}\chi=4.2, \\
d f-1\end{array}$ \\
\hline Male & 82 & 56.9 & 62 & 43.1 & 144 & $\begin{array}{l}\mathrm{d} \mathrm{l}=1 \\
\mathrm{p}=0.04\end{array}$ \\
\hline $\begin{array}{l}\text { Monthly family } \\
\text { income } \\
\leq \text { Rs. } 20,000 \\
\text { Rs. } 20,001-40,000 \\
\text { > Rs. } 40,000\end{array}$ & $\begin{array}{l}70 \\
56 \\
34\end{array}$ & $\begin{array}{l}57.4 \\
45.2 \\
47.9\end{array}$ & $\begin{array}{l}52 \\
68 \\
37\end{array}$ & $\begin{array}{l}42.6 \\
54.8 \\
52.1\end{array}$ & $\begin{array}{l}122 \\
124 \\
71\end{array}$ & $\begin{array}{c}\chi^{2}=3.2, \\
\mathrm{df}=2 \\
\mathrm{p}=0.1\end{array}$ \\
\hline $\begin{array}{l}\text { Educational level of } \\
\text { mother }\end{array}$ & & & & & & \\
\hline $\begin{array}{l}\text { Not attended school } \\
\text { or Grade } 1-5\end{array}$ & 4 & 2.5 & 7 & 4.3 & 11 & $\chi^{2}=2.8$ \\
\hline Grade 6-11 & 70 & 44.0 & 74 & 45.4 & 144 & $\mathrm{df}=3$ \\
\hline $\begin{array}{l}\text { Passed O/Level } \\
\text { examination }\end{array}$ & 46 & 28.9 & 53 & 32.5 & 99 & $\mathrm{p}=0.4$ \\
\hline $\begin{array}{l}\text { Passed A/Level } \\
\text { examination }\end{array}$ & 39 & 24.5 & 29 & 17.8 & 68 & \\
\hline $\begin{array}{l}\text { Educational level of } \\
\text { father }\end{array}$ & & & & & & \\
\hline $\begin{array}{l}\text { Not attended school } \\
\text { or Grade } 1-5\end{array}$ & 5 & 3.1 & 7 & 4.3 & 12 & \\
\hline Grade 6-11 & 62 & 39.0 & 61 & 37.4 & 123 & $\begin{array}{l}\chi=3.2, \\
d f=4 \\
n=0.5\end{array}$ \\
\hline $\begin{array}{l}\text { Passed O/Level } \\
\text { examination }\end{array}$ & 59 & 37.1 & 52 & 31.9 & 111 & \\
\hline
\end{tabular}




\begin{tabular}{|c|c|c|c|c|c|c|}
\hline $\begin{array}{l}\text { Passed A/Level } \\
\text { examination }\end{array}$ & 32 & 20.1 & 39 & 23.9 & 71 & \\
\hline $\begin{array}{l}\text { Mother's } \\
\text { employment } \\
\text { Housewives } \\
\text { Employed } \\
\end{array}$ & $\begin{array}{l}11 \\
2 \\
51 \\
\end{array}$ & $\begin{array}{l}49.6 \\
53.1\end{array}$ & $\begin{array}{l}11 \\
4 \\
45 \\
\end{array}$ & $\begin{array}{l}50.4 \\
46.9\end{array}$ & $\begin{array}{l}226 \\
96\end{array}$ & $\begin{array}{l}\chi^{2}=0.3, \\
\mathrm{df}=2 \\
\mathrm{p}=0.6\end{array}$ \\
\hline $\begin{array}{l}\text { Father's } \\
\text { employment } \\
\text { Semi-skilled labourer } \\
\text { Professional } \\
\text { Self employed } \\
\end{array}$ & $\begin{array}{l}87 \\
47 \\
22\end{array}$ & $\begin{array}{l}48.6 \\
59.5 \\
42.3\end{array}$ & $\begin{array}{l}92 \\
32 \\
30\end{array}$ & $\begin{array}{l}51.4 \\
40.5 \\
57.7\end{array}$ & $\begin{array}{l}179 \\
79 \\
52\end{array}$ & $\begin{array}{l}\chi^{2}=6.0 \\
\mathrm{df}=2 \\
\mathrm{p}=0.1\end{array}$ \\
\hline $\begin{array}{l}\text { No. of children in the } \\
\text { family } \\
1 \\
2 \\
3 \\
>3\end{array}$ & $\begin{array}{l}18 \\
73 \\
46 \\
26\end{array}$ & $\begin{array}{l}60.0 \\
49.3 \\
48.4 \\
53.1\end{array}$ & $\begin{array}{l}12 \\
75 \\
49 \\
23\end{array}$ & $\begin{array}{l}40.0 \\
50.7 \\
51.6 \\
46.9\end{array}$ & $\begin{array}{l}30 \\
158 \\
95 \\
49\end{array}$ & $\begin{array}{l}\chi^{2}=1.5 \\
\mathrm{df}=2 \\
\mathrm{p}=0.7\end{array}$ \\
\hline $\begin{array}{l}\text { Birth order } \\
1^{\text {st }} \text { child } \\
2^{\text {nd }} \text { child } \\
\geq 3^{\text {rd }} \text { child }\end{array}$ & $\begin{array}{l}83 \\
50 \\
29\end{array}$ & $\begin{array}{l}51.2 \\
30.9 \\
17.9\end{array}$ & $\begin{array}{l}86 \\
52 \\
21\end{array}$ & $\begin{array}{l}54.1 \\
32.7 \\
13.2\end{array}$ & $\begin{array}{l}169 \\
102 \\
50\end{array}$ & $\begin{array}{l}\chi^{2}=1.3 \\
d f=2 \\
p=0.5\end{array}$ \\
\hline
\end{tabular}

Figure 1: Distribution of the emotional intelligence scores among students $(\mathrm{N}=322)$

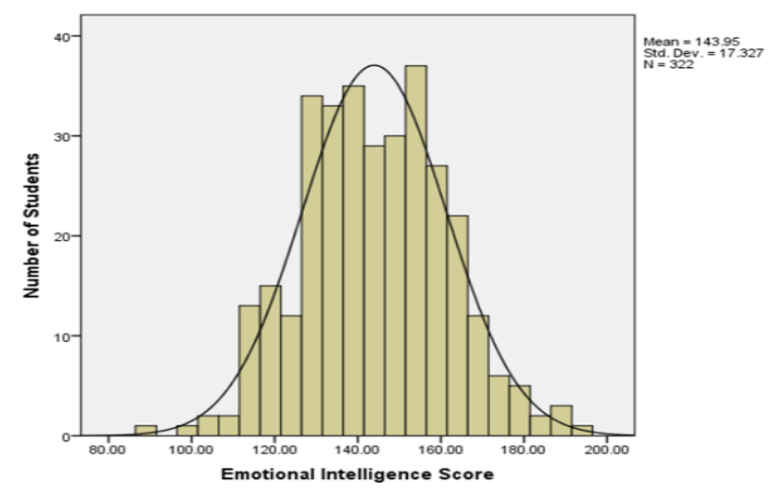

\section{References}

1. Goleman.D. Emotional intelligence. New York: Bantam 1995.

2. Goleman.D. Emotional Intelligence: Why it can matter more than IQ. New York: Bantam Press 2005.

3. Mayer.J.D and Salevoy.P. What Is Emotional Intelligence? In: Salovey.P, Sluyter.D.J (Eds.). Emotional development and Emotional intelligence. New York: Basic Books 1997;75113.

4. Goleman.D and Cherniss.C. The Emotionally Intelligent Work Place. Jossey- Bass Publications 2001.

5. Parker et al. Academic achievement in high school: does Emotional Intelligence matter? : Science Direct 2004; Vol37:p7

6. Petrides.K.V and Furnham.A. Trait Emotional intelligence: Psychometric Investigation with reference to established trait taxonomies. European Journal of Personality 2001; 15(6):425-448.

7. Jayawardane.L.N.A.C and Jayawardane.L.N.A.I. Assessing Emotional Intelligence of Sri Lankan high school students: A Case Study, Management Knowledge and Learning. International Conference 2012.

8. Mavrovelli.S and Sanchez.MJ. Trait Emotional Intelligence influence on academic achievement and school behaviour. British Journal of Educational Psychology 2011; V81:Issue1:112134.

9. Joshi.D and Dutta.I. Emotional Intelligence among secondary students: Role of Gender and Type of School. MIER Journal of Educational Studies, Trends and Practices 2014; Vol4:No.2:167-182. 
10.Nara.A. Study the Emotional Intelligence of school students of Haryana in respect of sex and locale. International Journal of Research 2014;1:Issue3:33-39.

11.Goleman.D. Are women more emotionally intelligent then men. Psychology Today 2011; http://www.psychologytoday.com/blog/the -brain-and-emotionalintelligence/201104/arewomen-more-emotionally-intelligent-than-men. accessed on $16 / 7 / 15$

12.Aznar.A and Tenenbaum.H.R. Do parents nurture emotional Intelligence in daughters more than in sons? School of Psychology: University of Surrey 2014.

13.Devi.R and Narayanamma. An empirical study on demographic correlates of Emotional Intelligence of engineering students. Indian Journal of Management 2014; Vol7. http://www.indianjournalofmanagement.com/in dex.php/pijom/article/view/59290/0, accessed on $16 / 7 / 15$

14.Harrod.N.R and Scheer .S.D. Adolescence 2005;Vol.40:P159. 